\title{
中性子水分検層と環境同位体による第三紀泥岩地すべり地の 排水トンネルの抑制効果の評価
}

\author{
Evaluation of the drainage effect by drain tunnel in Tertiary mudstone landslide area using
}

a neutron moisture logging and environmental isotopes in groundwater

\author{
石田 聡a ${ }^{*}$ ・原 郁男 ${ }^{\mathrm{b})} \cdot$ 土原健雄 ${ }^{\text {a) }} \cdot$ 今泉眞之 ${ }^{\text {a) }}$ \\ Satoshi ISHIDA, Ikuo HARA, Takeo TSUCHIHARA and Masayuki IMAIZUMI
}

\begin{abstract}
In order to develop the evaluation method for the drainage effect by drain tunnel, monitoring of water content using neutron moisture logging in the drainage boring pipe for 19 months and environmental isotope concentrations (Tritium and Radon : ${ }^{222} \mathrm{Rn}$ ) in groundwater from the drainage boring pipes for five years were carried out after the construction of drain tunnel. The drain tunnel is $1.25 \mathrm{~m}$ (diameter) $\times 500 \mathrm{~m}$ (length) at $50 \mathrm{~m}$ underground with drainage boring pipes, which are expected to drain superfluous water around the sliding surface of an active landslide in Tertiary mudstone area, Niigata Prefecture. Consequently, the monitoring of water content showed a remarkable decreasing with about $8 \%$ of water content around the sliding surface for the first four months and subsequently slight decreasing. The tendency of decreasing of water content corresponds with the fluctuation pattern of discharge water volume from drainage boring pipes. The monitoring of tritium and ${ }^{222} \mathrm{Rn}$ concentrations revealed that the groundwater around the tunnel was recharged from rain before 10 years and the unsaturated zone around tunnel was occurred. These change of groundwater flow after construction of drain tunnel certifies that the monitoring techniques are useful methods for evaluation of the effect by the drain tunnel.

Key words : drain tunnel, radon, tritium, neutron moisture logging, water content

和文要旨

新潟県板倉町の活動中の大規模地すべりの抑制工として建設された排水トンネル内の観測孔において，排水トンネルの効果判定 のために，中性子水分検層による含水比変化と環境同位体（トリチウムとラドン）濃度変化のモニタリングを行った。その結果， すべり面付近の含水比は 4 ケ月間で約 $8 \%$ 低下しその後は漸減した。含水比の低下は排水ボーリングからの排水量の低下と調和的 であった。また環境同位体の測定から，排水ボーリングから排水される水はかん養後10年以上経過している事が明らかになると共 に, 排水が定常状態に達してトンネル周辺地山に不飽和の部分が生じていると推定され, 中性子水分検層と環境同位体によるモニ タリングは排水トンネルの効果判定に有効であることが実証された。 キーワード：排水トンネル, ラドン, トリチウム, 中性子水分検層, 含水比
\end{abstract}

\section{1.はじめに}

我が国では地すべり防止対策として，一般的に抑止工 および抑制工が現場に応じて組み合わされて実施されて いる。近年国営事業等で対象となっている大規模地す心゙ りに対しては，想定しているすべり面深度が深い場合， 抑止工の施工が難しいため, 抑制工，特に排水トンネル 等の地下水排除工中心の対策が行われている。地下水排 除工の施工効果は，観測井の地下水位変化によって推定 されることが一般的である。しかし，すべり面の深度が 深い岩盤地すべりの場合, 岩盤内の亀裂の発達状況等に 地下水流動が規制されること等の理由から，断層などの 大規模な水みちが明らかになっている場合を除き，限ら れた数の観測井によってすべり面及びその周辺の地下水 流動状況の変化を正確に観測することは困難な場合が多い。

竹内ら（1993）は地下水排除工の効果判定法として, 電気探査, 地温測定調查 ( $1 \mathrm{~m}$ 深地温), 排水量測定の

\footnotetext{
* 連絡著者/corresponding author
a) 独立行政法人 農業工学研究所

National Institute for Rural Engineering

National Institute for Rural Engineering
厂 305-8609 茨城県つくば市観音台2-1-6

T $305-8609$ 茨城県つくば市観音台2-1-6
2-1-6. Kannondai, Tsukuba City, Ibaraki Pref., 305-8609, Japan

b ) 農林水産省 北陸農政局

The Ministry of Agriculture. Forestry and Fisheries of Japan, Hokuriku Regional Agricultural Administration Office
}

実施例と効果を示している。このうち電気探査，地温測 定調査は主に浅層地下水を調查対象としており, 排水卜 ンネルが施工される深度 $50 \mathrm{~m}$ 以深に打ける地下水流動状 況の変化を捉えることは難しい。また，排水量の変化は 排水トンネル周辺の地下水流動状況変化を表す一つの指 標となるが，単純に排水量の大小が即抑制効果に比例す るとは言えず（竹内ら1993），排水トンネル施工後の地 下水流動状況の変化を捉えて地すべり抑制工の効果を評 価する効果的な手法は確立されるに至っていない。

仲野ら（1993）は新潟県東頸城丘陵の椎谷・寺泊層泥 岩の地すべり地を対象として, 地すべり粘土の完全軟化 状態に押ける有効応力と含水比の関係が採取地点によら ず一定の直線関係にあることを明らかにした。その関係 （完全軟化状態含水比曲線）と, 泡式ボーリング・3 重 管式サンプリングによって得られた試料の自然含水比測 定によって得られた含水比プロファイルとの比較から， すべり面の位置およびそこにかかる被圧地下水やパイピ ングなどによる空洞的な水みちの存在を推定した。また 北陸農政局（1993）は，同じ第三紀層地すべり地の泥岩 を対象として，ボーリングコアの自然含水比を測定する ことにより，すべり面位置及び間隙水圧が推定できるこ 
とを示した。今泉（1996）は，地すべり地内のボーリン グ孔内において中性子水分検層を行い, 孔内の鉛直含水 比分布と，仲野ら（1992）が示した完全軟化含水比曲線 を比較し，すべり面を特定出来ることを示した。これら の研究ではいずれも 1 回の含水比測定ですべり面を特定 している，一方地下水排除工が施工されている現場にお いては，すべり面深度がある程度特定されているので, すべり面を貫く観測孔において含水比の測定を定期的に 行い, すべり面付近の含水比変化を捉える事が出来れば, 測定值を変化させる要因としては測定部周辺の水分量変 化のみと考えられるので, 地下水排除工の効果を判定す ることが可能と考えられる。しかし，これまでこの様な 視点に立った研究例はない。

排水トンネル等の大規模地下水排除工から排出される 地下水は, 施工深度が深いことから比較的長い期間地下 に滞留していたと考えるのが一般的である。ところが, 排水箇所によっては地表からの水が数日程度の短期間で 到達している可能性もある。この様な水みちが存在して いる場合，すべり面の含水比が低下した後も，集中豪雨 時に浸透量が一挙に増大し，すべり面に大きな間隙水圧 を与える可能性があるので，水抜きボーリングの施工間 隔を密にする等の対策を講じる必要がある。このため地 下水排除工の効果を判定するためには, すべり面付近の 含水比変化を測定するのみでは不十分であり, 地下水の 滞留時間も効果判定の重要な要素となる可能性がある。 地下水の滞留時間を推定するには地下水中のラドン, ト リチウム等の放射性同位体濃度を測定することが有効で あるが，地すべり地の排水トンネルにおいて深層の地下 水を長期的に測定し, 地下水の滞留時間や地下水環境の 変化を考察した研究例はこれまでない。

本論文では北陸農政局によって施工された地すべり排 水トンネルに掞いて, 中性子水分計を用いたトンネル周 辺岩盤の含水比測定および地下水のラドン・トリチウム の放射性同位体濃度の測定等を行い, 掘削後の排水トン ネル周辺の地下水流動変化を推定し, 提示する調査項目 の排水トンネル施工効果判定への適用性について考察し た。本研究の一部は, 原子力委員会の評価に基づき, 文 部科学省原子力試験研究費により実施されたものである。

\section{2. 調査地区の概要}

\section{1 地形・地質}

調査地は農林水産省直轄地すべり対策事業板倉地区内 であり, 新潟県新井市から南東約 $5 \mathrm{~km}$ の中頸城郡板倉 町の南部山間地帯 (東頸城丘陵) に位置している釜塚 · 段子差地すべりブロックである（図－1）。東頸城丘陵 は標高 $200 \mathrm{~m} \sim 500 \mathrm{~m}$ の緩傾斜地である。

調查地域周辺には新第三系, 第四系が厚く堆積してお り, その層厚は $5,000 \mathrm{~m}$ 以上及ぶ。これらの層序は下 位より富倉層 (上部中新世), 長沢 · 白岩層 (鮮新世), 土路層・猿橋層・小濁層（下部更新世）に区分されてい

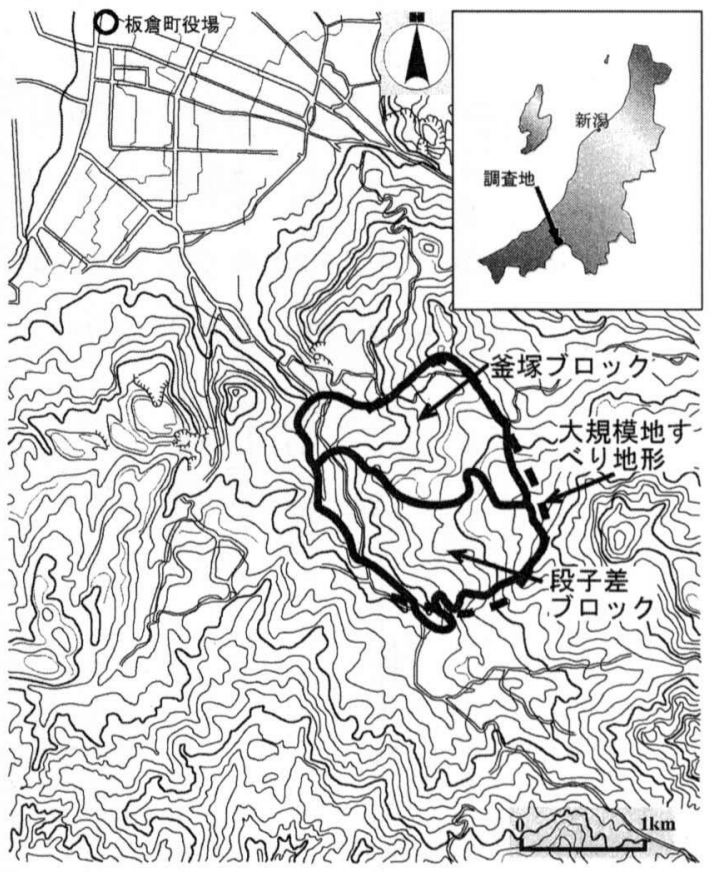

\section{図-1 調査地位置図}

Fig. 1 Location map of study area

表-1 調査地区周辺の地質層序表

Table 1 Stratigraphic classification of study area

\begin{tabular}{|c|c|c|c|c|}
\hline \multicolumn{2}{|c|}{$\begin{array}{l}\text { 地質 } \\
\text { 時代 }\end{array}$} & \multicolumn{2}{|c|}{ 地層名 } & 岩＼cjkstart相 \\
\hline \multirow{6}{*}{$\begin{array}{l}\text { 第 } \\
\text { 四 } \\
\text { 紀 }\end{array}$} & \multirow{3}{*}{\multicolumn{2}{|c|}{$\begin{array}{l}\tilde{T} \\
+ \\
\end{array}$}} & & \multirow[t]{3}{*}{ 泥 · 砂 · 砂磞 } \\
\hline & & & & \\
\hline & & & & \\
\hline & 更 & & & 泥・砂・砂磁 \\
\hline & 新 & & 蜀層 & シルト岩、砂岩䂪岩 \\
\hline & 世 & \multicolumn{2}{|c|}{ 猿橋層 } & $\begin{array}{l}\text { シルト岩、砂岩、 } \\
\text { 礫、安山岩 }\end{array}$ \\
\hline \multirow{7}{*}{$\begin{array}{l}\text { 新 } \\
\text { 第 } \\
\text { 三 } \\
\text { 紀 }\end{array}$} & \multirow{6}{*}{$\begin{array}{l}\text { 群 } \\
\text { 听 } \\
\text { 世 }\end{array}$} & \pm & 上部 & シルト岩、砂岩 \\
\hline & & 路 & & (安山岩質凝灰岩挟有) \\
\hline & & 層 & 中部 & $\begin{array}{l}\text { 磻岩（凝灰岩、 } \\
\text { シルト岩、砂岩挟有） }\end{array}$ \\
\hline & & & 下部 & 砂岩、シルト岩 \\
\hline & & \multicolumn{2}{|c|}{ 白岩層 } & 塊状青灰色細粒砂岩 \\
\hline & & \multicolumn{2}{|c|}{ 長沢層 } & $\begin{array}{l}\text { 青灰色塊状泥岩 } \\
\text { (一部砂岩泥岩互層) }\end{array}$ \\
\hline & $\begin{array}{l}\text { 中 } \\
\text { 新 } \\
\text { 世 }\end{array}$ & \multicolumn{2}{|c|}{ 富倉層 } & $\begin{array}{l}\text { 暗灰色〜黒色塊状泥岩 } \\
\text { (泥岩優勢砂岩泥岩、 } \\
\text { 細粒酸性凝灰岩、 } \\
\text { 黒色ガラス質粗粒 } \\
\text { 安山岩質凝灰岩挟有) }\end{array}$ \\
\hline
\end{tabular}

る（中村1982）。各層の岩相は主に海成の泥岩, 砂岩, 碟岩からなり，一部安山岩溶岩，凝灰角碩岩，酸性凝灰 岩を挟在する。調査地区には, 新潟県標準層序の寺泊層, 椎谷層に相当する, 泥岩を主体とした富倉層が分布して いる。これらの地層は構造運動による著しい裮曲・断層 作用を受け，隆起後の風化作用により軟弱化して地すべ りを発生させる要因となっている（仲野ら 1992）。本地 区に打りる年間降雨量は2, 948mm，積雪深は $2 \sim 3 \mathrm{~m}$, 不圧層の地下水位はGL-3〜0mである(北陸農政局2001)。

釡塚・段子差地すべりブロックを取り囲む様に大規模 
地すべり地形が発達している。この地すべり地形内には, 二次・三次ブロックと推定される地すべりブロックが複 数見られる(図-2)。対策工の中心となっている地す ベりブロックの規模は幅 $1 \mathrm{~km}$, 長さ $2 \mathrm{~km}$, 最大層厚 140 $\mathrm{m}$ 以上で，GPSによって年間 $3 \sim 4 \mathrm{~cm}$ 程度の速度での 移動が確認されている（原ら2003）。排水トンネルは, 大規模地すべり地形内で，境界線に平行するように配置 されている。

\section{2 排水トンネル}

当該地すべり地においては, 巨大地すべりの原因と なっている深層地下水の排除を行うため大規模抑制工と して排水トンネルが施工されている（細谷1992, 原ら 2003など)。排水トンネルは 1 号トンネルから 3 号トン ネルまで 3 本施工されており，いずれも2004年 5 月現在, 本体掘削及び水抜きボーリングの施工は完了している。 図- 2 に今回の調査対象である 2 号トンネル及び 3 号卜 ンネルの位置を示す。表- 2 に今回の調査対象である 2 号排水トンネルの施工期間を示す。トンネルの本体掘削 は1995年 9 月から約 2 ヶ年間で施工された。水抜きボー リング工はトンネル本体の掘削後, 1998年 3 月から約 9 ケ月間で施工された。図 -3 に 2 号トンネルに添った 地質断面図，図一 4 にトンネル施工断面図を示す。大規 模すべり面は，ボーリング調査と 2 号トンネル壁面の観 察から推定された。すべり面は 2 号トンネルとほぼ同じ 標高をうねるように分布している。排水ボーリングはト

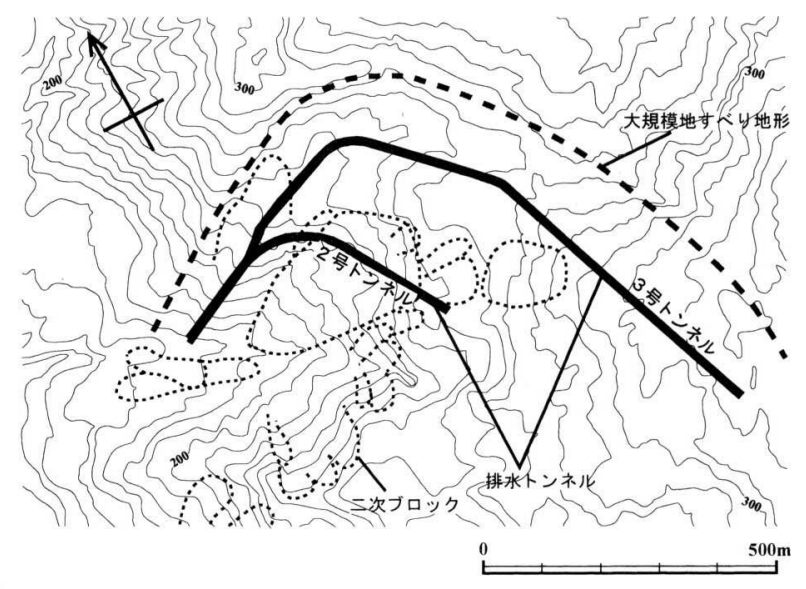

図一2 排水トンネル位置図

Fig. 2 Location map of drain tunnels
ンネル内から, 45 度上向きの角度で施工（一部はトンネ ル底面から45度下向きの角度で施工）されている。

\section{3. 試験方法}

排水トンネル掘削後から定期的に中性子水分計によっ てすべり面付近の地山の含水比を測定すると共に，地下 水の滞留時間を調查する目的で地下水中の放射性同位体 （ラドンおよびトリチウム）濃度を測定した。

\section{1 含水比の測定}

現地測定に用いた中性子水分計はソイルアンドロック 社製SRM- $1 \mathrm{~d}$ 型（外径 $42.7 \mathrm{~mm}$ ) である。この測定器 は ${ }^{252} \mathrm{Cf}$ 線源とし，熱中性子検出器に ${ }^{3} \mathrm{He}$ 比例計数管を 用いている。測定深度はプローブの線源位置（プローブ 先端からの距離 $15 \mathrm{~cm}$ ）で代表させた。なお線源は半減 期2. 65 年で減衰していくため, 测定時期の異なる計数值 を単純には比較できない。また測定機内の電子機器の温 度ドリフト, 経年変化等によって対象物の含水比が同じ でも，測定の度に計数率が変化する。Dennis and John

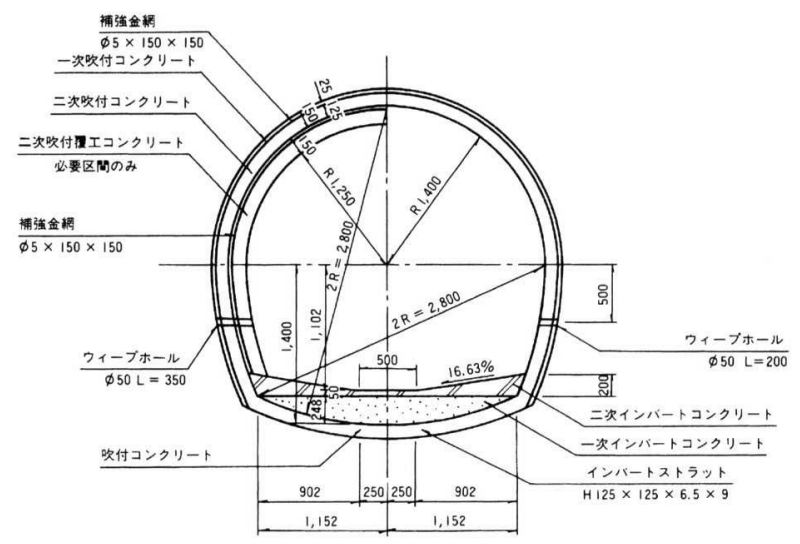

図一 4 排水トンネル断面図（単位mm：北陸農政局2001） Fig. 4 Section of drain tunnel

表一 $2 \quad 2$ 号排水トンネル施工期間

Table 2 Construction term of the second drain tunnel

\begin{tabular}{c|c|c}
\hline \hline 工事内容 & 開始 & 終了 \\
\hline トンネル本体掘削 & 1995.9 .4 & 1997.10 .30 \\
\hline 水抜き工事 & 1998.3 .31 & 1998.12 .25 \\
\hline
\end{tabular}

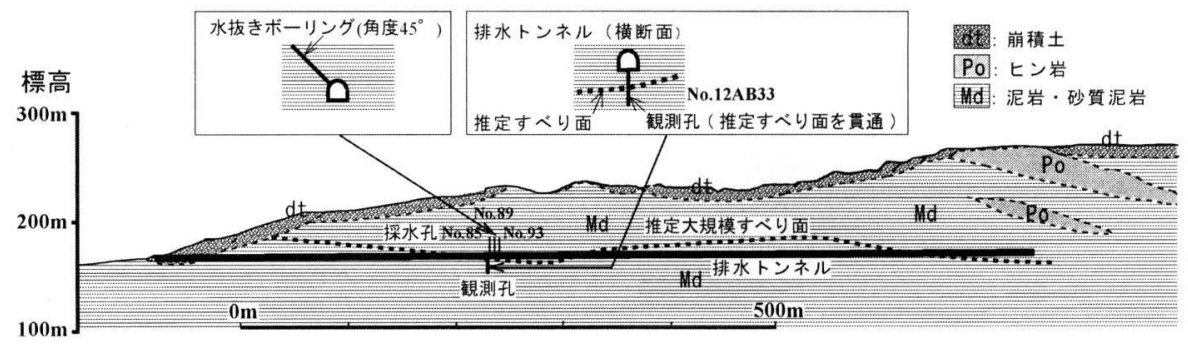

図一－2 2 号排水トンネル地質断面図

Fig. 3 Geological section of drain tunnel 
（1979）はこの様な機械的な誤差を回避するには，現地 における測定值を含水比が既知の物質の測定值 (標準值) に対する計数率比に換算して扱うことが有効であるとし ている。このため現地測定の前後にstandard boxでの測 定を行い標準值を求め，標準值に対する現地測定值を計 数率比として算出し, 測定時期の異なるデー夕の対比に 用いた。

中性子水分計を使用する場合，測定值と水分率の関係 をあらかじめ求めておかなければならない。ここでは今 泉（1996）の方法を参考に，径 $650 \mathrm{~mm}$ ，高さ1,000mm のドラム缶（容積約 $200 \ell ） に$ 観測孔と同じ孔径，材質 のケーシングパイプを立て，周りに一定の水分状態に調 整された試料を詰めた後，中性子水分計をパイプに挿入 して測定を行った。試料には粘土, 砂, 碟を用い, 試料 の水分状態を変化させ, 計数率比と含水比の関係を図化 しキャリブレーション式を求めた（図－5）。この式に より現地で得られた測定值を含水比に換算した。本調査

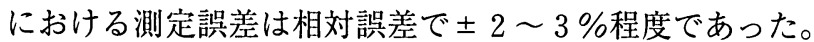

現地測定は観測孔掘削直後, 2 ケ月後, 4 ケ月後, 5 ケ 月後, 12 ヶ月後, 16 ケ月後, 19 ケ月後の計 6 回行った。測 定にあたっては孔口から $10 \mathrm{~cm}$ 間隔で下方にプローブを 移動させ，それぞれの位置での測定時間は 10 秒間とした。

観測孔は2000年に上越農地保全事業所によって水分検 層専用に掘削されたNo.12AB33孔で，排水トンネル底 面から推定すべり面（トンネル底面からの推定深度約 6 m）を貫く様に鉛直下方にノンコア掘削されている（図 $-3)$ 。保孔管は無孔䘏ビパイプとし，孔口からの水の 浸透を防止するため，孔壁と保孔管の間はモルタルを充 填した。中性子水分計について開発ら（1979）は測定機 内部の電子回路の安定性, 回帰式の不正確さ, 検層器と 孔壁のクリアランス, 温度効果について検討し, 検層器 と孔壁のクリアランスが大きくなると測定值のばらつき が大きくなるとしており，保孔管の口径は水分計のプ ローブが挿入可能な最小のもの（VP50）とした。

\section{2 地下水中のラドン濃度の測定}

2 号排水トンネルにおいて施工された上向きの排水

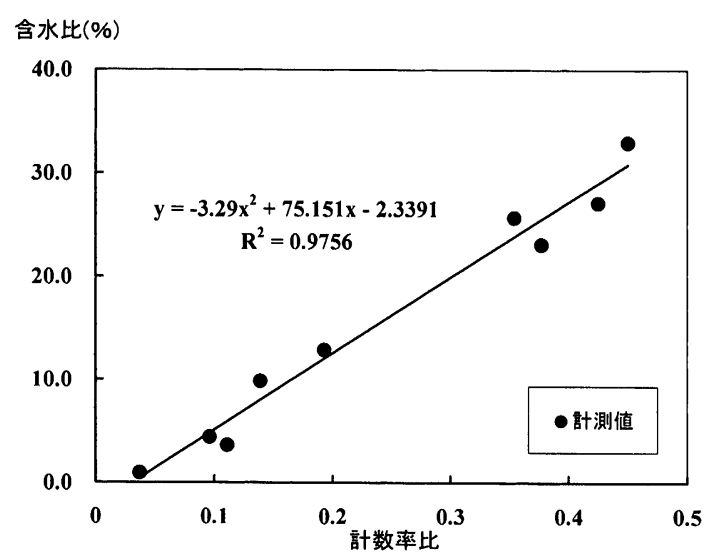

図－5 中性子水分計校正実験結果

Fig. 5 Calibration result of neutron moisture meter
ボーリング孔のうち，地下水の排水量が比較的多く，中 性子水分検層を行った12AB33孔の近傍に位置している (図－3）No.85，No.89，No.93の 3 孔について定期的 に採水を行い，地下水中のラドン濃度を測定した。それ

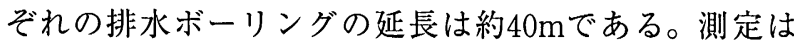
1998年12月10日から2003年12月 3 日まで 5 年間，延べ 19 回行われた。

ラドン濃度の測定にはトルエン抽出法を採用した。現 地で $500 \mathrm{~m} \ell$ の試料を採水し, シンチレーター（発光剂） を溶解させたトルエン $40 \mathrm{~m} \ell$ を加えて攪拌，静置し，分 離したトルエン $20 \mathrm{~m} \ell$ をガラスバイアルに回収する。回 収したバイアルは研究室に持ち帰り, 液体シンチレー ションカウンタ（パッカード社製2250CA）で測定を行っ た。測定時間は 1 試料 50 分で，検出限界は約 $0.037 \mathrm{~Bq} /$ $\ell$ である。今回の調査試料の測定誤差は相対誤差で約 $3 \%$ あった。ラドン濃度の単位はBq/ $\ell$ である。

\section{3 地下水中のトリチウム濃度の測定}

ラドン濃度を測定した排水ボーリング孔と同じNo. 85, No. 89, No.93の 3 孔について概ね 1 年毎に採水を行い, トリチウム分析を行った。

天然の水に含まれるトリチウムは低濃度であるため測 定前に電気分解によって試料を濃縮した。そのため, 1 サンプル当たり約 $3 \ell$ の試料を採取し，電気分解によっ て $2,500 \mathrm{~m} \ell$ の試料を二段階の濃縮で約 $10 \mathrm{~m} \ell$ まで減容し た。その濃縮試料 $5.4 \mathrm{~m} \ell$ をガラスバイアルに移し， シ ンチレーター $14.6 \mathrm{~m} \ell$ を加え, 前述の液体シンチレー ションカウンタで測定した。なお，本論文ではトリチウ ム濃度の単位にTU（トリチウムユニット）を用いた。 TUはトリチウム濃度を表す単位で，水素原子 $10^{18}$ 個中の トリチウム原子の数である。SI単位であるべクレルとの 関係は, $1 \mathrm{TU}=0.12 \mathrm{~Bq} / \ell$ である。

\section{4. 試験結果}

\section{1 含水比測定結果}

図 - 6 に12AB33孔の含水比を示す。縦軸はトンネル 底面（インバート上面）からの深度，横軸は地山の含水 比を示す。

最初に観測を行った2000年 8 月には深度1.0〜2.0mで 含水比は25〜28\%であった。深度2.0〜3.0mまで含水比 は減少し，深度 $3 \mathrm{~m}$ 付近で約 $17 \%$ の極小値を取った。 3.0 $\mathrm{m} \sim 4.0 \mathrm{~m}$ までは一旦 $25 \%$ 程度まで増加した後，また減 少した。深度4.0〜 5.3mでは含水比は17〜 19\%の範囲で 推移した。深度 $5.3 \mathrm{~m}$ 以深では含水比は増加し， $5.7 \mathrm{~m}$ で 約 $29 \%$ の極大值を示した。 2 ヶ後の観測では全体的な 含水比分布は殆ど同じであったが，深度 $4.2 \mathrm{~m}$ 以深の含 水比分布が若干異なっている。特に $5.7 \mathrm{~m}$ 付近の極大值 部分が減少している。4ケ月後の観測では含水比が極大 值を取っていた深度の殆どで含水比が減少した。12ヶ月 後の含水比分布は，観測開始時と比べて全体的に低下し ており，3.0〜 4.0m と $5.7 \mathrm{~m}$ 付近の極大值部分は観測開 


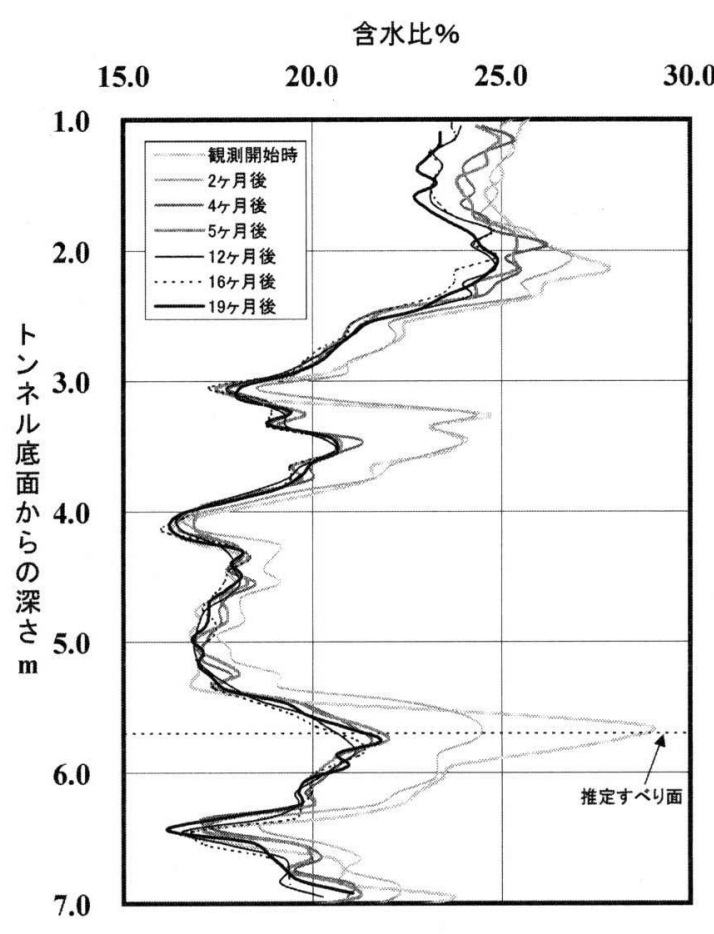

図一６ 12AB33孔における含水比の経時変化

Fig. 6 Fluctuation of water contents at 12AB33

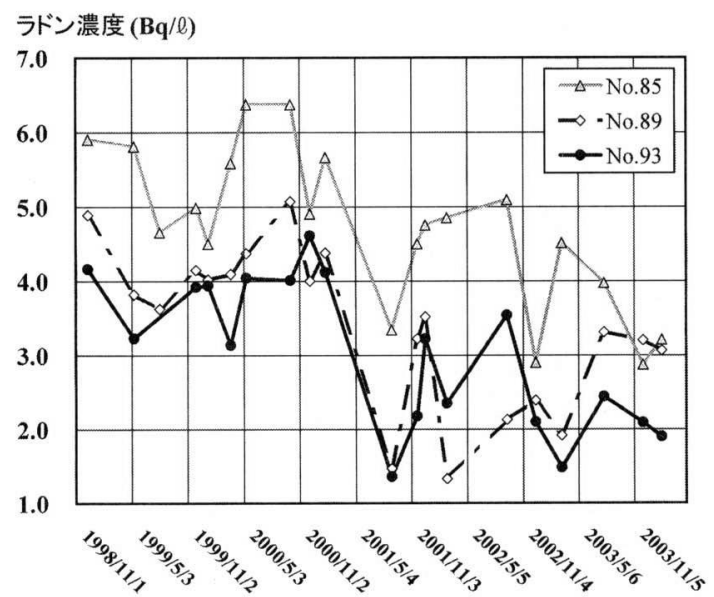

図ー7＼cjkstart排水ボーリング孔において採取した地下水のラドン 濃度

Fig. 7 Fluctuation of ${ }^{222} \mathrm{Rn}$ concentration in groundwater at drain borings

始当初と比べて顕著に減少している。16ヶ月後，19ケ月 後の含水比分布は, 12 个後の含水比分布とほぼ同じで ある。

\section{2 ラドン・トリチウム濃度測定結果}

図 -7 に 2 号トンネルNo. 85 ，No. 89，No.93水抜き ボーリング孔における排水中のラドン濃度の経時変化を 示す。

No. 85孔におけるラドン濃度は1998年12月～2001年 1 月の期間，約 $4.5 \sim 6.5 \mathrm{~Bq} / \ell$ の範囲を推移していたが, それ以降は約3.0〜 $5.0 \mathrm{~Bq} / \ell$ の範囲を推移し, $5.1 \mathrm{~Bq} / \ell$ を越える值は観測されなかった。No.89孔におけるラド
表一 3 排水ボーリングにおいて採取された地下水のトリチ ウム濃度測定結果

Table 3 Fluctuation of tritium concentration at second drain tunnel

\begin{tabular}{l|c|c|c|c}
\hline \hline 孔名 & $1998 / 12$ & $1999 / 5$ & $2000 / 5$ & $2001 / 8$ \\
\hline No.85 & & $3.5 \mathrm{TU}$ & & $5.1 \mathrm{TU}$ \\
\hline No.89 & $3.0 \mathrm{TU}$ & & $5.1 \mathrm{TU}$ & $6.0 \mathrm{TU}$ \\
\hline No.93 & & $5.5 \mathrm{TU}$ & & $5.2 \mathrm{TU}$ \\
\hline
\end{tabular}

ン濃度は1998年12月～2001年 1 月の期間, 約 $3.5 \sim 5.0 B q$

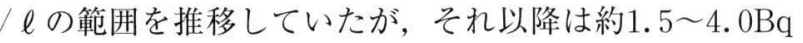
$/ \ell$ の範囲を推移し， $4.0 \mathrm{~Bq} / \ell$ を越える值は観測されな かった。No.93孔におけるラドン濃度は1998年12月〜

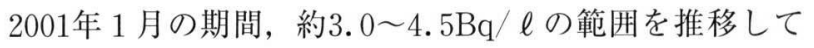
いたが，それ以降は約 $1.5 〜 3.5 \mathrm{~Bq} / \ell の$ 範囲を推移し， $3.6 \mathrm{~Bq} / \ell$ を越える值は観測されなかった。いずれもラ ドン濃度は $2 \mathrm{~Bq} / \ell$ 程度の変動幅を持つが, 季節等との 関係は特に見いだせなかった。またラドン濃度はいずれ の排水ボーリング孔においても全体的に低下傾向にある。

表 -3 に 2 号トンネルNo. 85 ，No. 89, No.93水抜き ボーリング孔における排水中のトリチウム濃度の観測結 果を示す。測定值は3.0〜6.0TUの範囲内にあった。

\section{5. 考 察}

\section{1 水分検層}

すべり面は幾何学的に単一な面ではなく，ある厚みを 持ったゾーン的なものであり，全体的に粘土化していて も，その中に無数の亀裂を伴うことが知られている（申， 1989)。集水井でのすべり面の観察から次のようなこと が明らかになっている（紀平，1989）。

(1)すべり面には上下の地層とは明らかに異なる $3 \sim 8$ $\mathrm{cm}$ の厚さの粘土が存在する。

(2)すべり面粘土の内部からの地下水の滲出は認められな い。すべり面から数 $\mathrm{cm}$ 上位の岩片混じり粘土の岩片 の間隙や岩片と粘土の境，およびすべり面から 2 〜 $\mathrm{m}$ 上位で地下水の渗出が観察される。

(3)すべり面の含水比は $47 \%$ ～53\%であり，すべり面直上 の粗粒成分が混じった粘土の含水比 $(36 \sim 47 \%)$ に比 較して数\%高い状態にある。

以上の観察からすべり面自体は不透水層であることがわ かる。従って，地すべりの安定解析でいうことろの「す ベり面に働く間隙水圧」は, せん断面とは多少ずれた上 位に分布する地下水の水圧が，粘土のせん断亀裂帯を介 してせん断面に揚圧力として働くと考えるべきである (紀平，1989)。

今泉（1996）は第三紀泥岩地すべり地において，仲野 ほか（1992）の完全軟化含水比曲線をプロットし，自然 含水比が極大值を取り，この曲線を越えている部分が完 全軟化強度粘土層（初生すべり面）の位置になる事を示 
している。既往の調查より12AB33孔掘削地点のすべり 面は深度 $6 \mathrm{~m}$ 前後と推定されていること, 含水比が深度 $5.7 \mathrm{~m}$ で極大值である事から，すべり面は深度 $5.7 \mathrm{~m}$ 付近 に存在すると考えられる。

図－8に観測孔12AB33における含水比の観測期間毎 の差分を示す。図で中心線より左側の線が含水比の低下 量, 右側の線が含水比の増加量を示す。観測開始〜 2 ケ 月後の期間では深度 $4.2 \mathrm{~m} \sim 5.5 \mathrm{~m}$ の区間で含水比が増加， 哚度5.6 6.4mの区間で含水比が減少している。観測開 始 2 ヶ月後〜 5 ヶ月後の期間では，ほぼ全区間において 含水比が減少している。観測開始 5 ケ月後〜12ヶ月後の 期間では，ほぼ全区間において含水比が僅かに減少して おり，観測開始12ヶ月後〜19ヶ月後の期間では全体的に 含水比はほぼ横ばいである。図 - 9 に梁度 $5.7 \mathrm{~m}$ 地点に おける含水比の経時変化を示す。すべり面のある梁度 5.7 $\mathrm{m}$ 付近の含水比は, 観測開始〜 4ヶ月後の間は概ね $2 \% /$ 月の割合で減少し, その後は漸減もしくはほぼ横ばいで ある。当初の 4 ヶ月間で減少した含水比は約 $8 \%$ ある。 図－10に観測孔12AB33近傍の排水ボーリング 5 孔か らの排水量合計の経時変化を示す。排水量は排水ボーリ

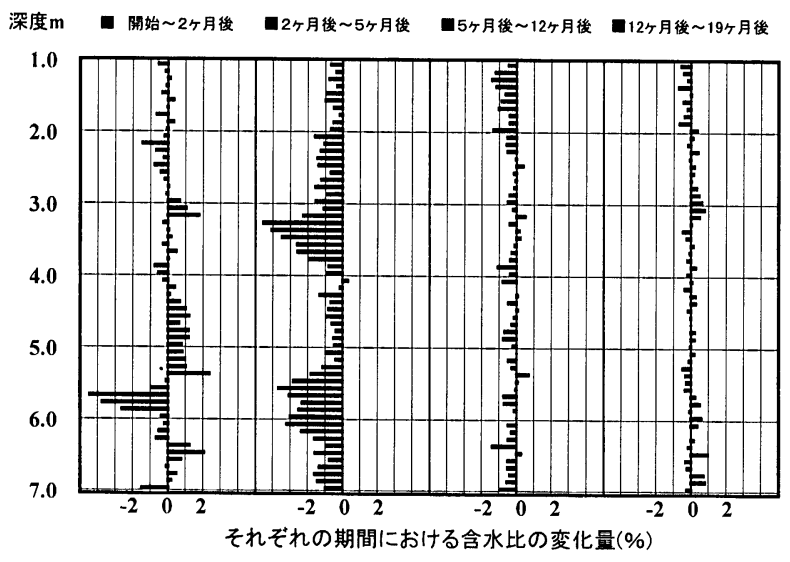

図一 8 含水比変化量

Fig. 8 Difference of water contents

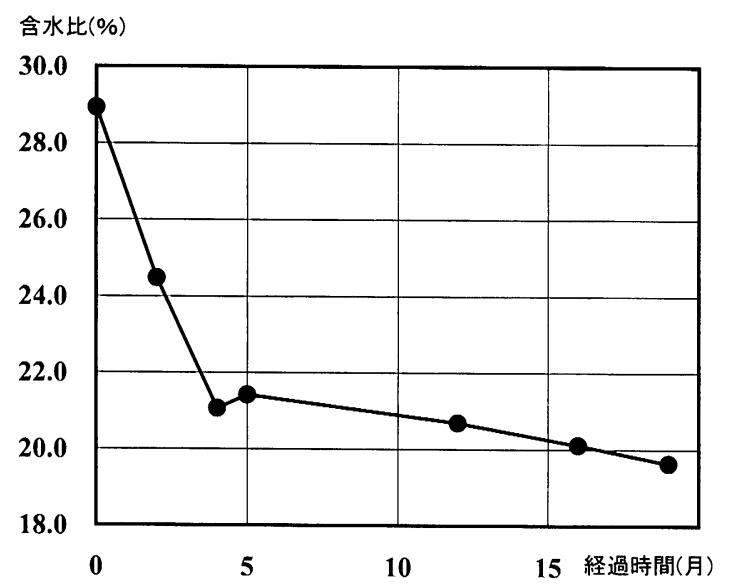

図一 9 すべり面における含水比の経時変化

Flg. 9 Fluctuation of water contents around sliding surface
ング掘削直後の1999年 1 月の $3.2 \ell / \min$ から 2001 年 1 月 (観測開始 5 ケ月後) まで, $2 \ell / \mathrm{min}$ 前後の比較的高い レベルで増減を繰り返し，全体としては減少傾向にある。 それ以降は $1.4 \ell / \mathrm{min} か ら 0.8 \ell / \mathrm{min}$ とほぼ横ばいに 近い渐減傾向を示している。排水量が $2 \ell / \mathrm{min}$ 前後の 比較的高いレベルであった期間は，すべり面付近で比較 的大きい含水比の減少が見られた期間とほぼ一致してお り，逆に排水量低下後に横ばい傾向を示している期間は, 含水比の変化が少ない期間と一致している。このことは 排水トンネル施工直後は排水ボーリングの排水能力に対 して間隙水が過剩であるため, 排水ボーリングからの排 水量は短期間では減少せずに漸減し，その間すべり面付 近の含水比も減少を続けるが, 一定期間が経過し, 過㮃 な間隙水が排出されトンネルからの排水が供給される地 下水とつり合って定常状態に達してくると排水量が減少 し，すべり面付近の含水比も安定することを示している と考えられる。本手法によって測定されるすべり面付近 の含水比の経時変化が，排水トンネルの施工効果の一つ の指標に成りうると言える。

\section{2 ラドン・トリチウム濃度}

降水中のトリチウム濃度は1960年代に世界各地で行わ れた水爆実験の影響で高濃度を示しているが，近年では その影響がなくなり $10 \mathrm{TU}$ 程度で推移している。地上に 到達した降水の一部は，地下に浸透し，含まれているト リチウムは半隇期 12.3 年の速さで減衰していくことから, ピストン流を仮定することにより，地下水の滞留期間を 推定する事が出来る（Andersenら1974，今泉ら2000な ど)。図ー11に，東京都および茨城県つくば市における 降水のトリチウム濃度の年平均值の経年変化を示す。 1961 1983年の東京都の值は東京都（IAEA1969ほ か), 1978年以降のつくば市の值は農業工学研究所が分 析した濃度である。新潟県においては降水のトリチウム 濃度は測定されていないが，高島（1991）によると日本

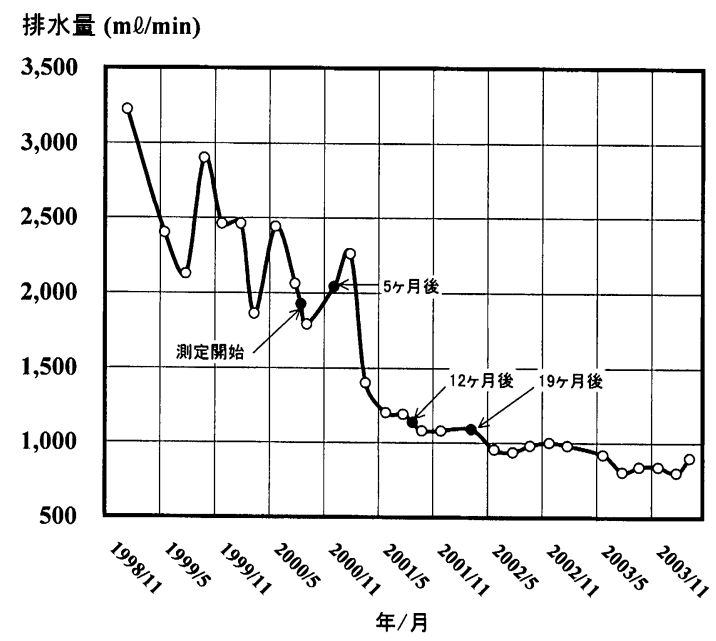

図ー10 12AB33孔近傍の排水ボーリングからの排水量

Fig. 10 Fluctuation of the volume of discharged water at drain boring near $12 \mathrm{AB} 33$ 


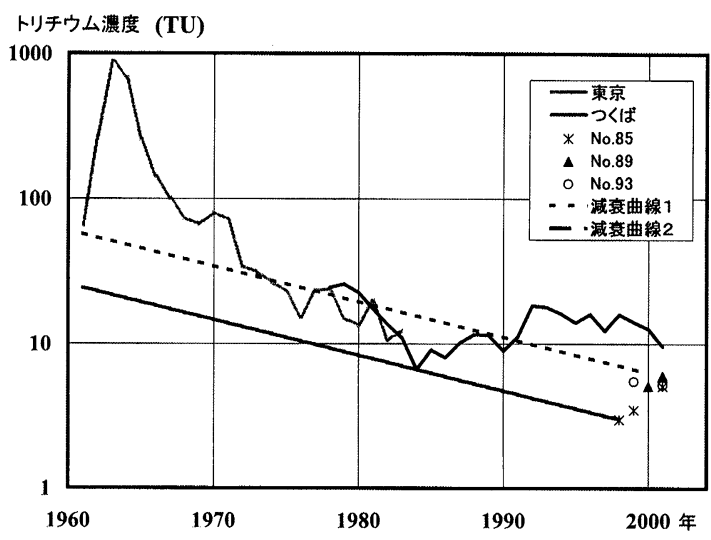

図ー11＼cjkstart東京都及びつくば市における降水のトリチウム濃度 と排水ボーリングから採取された地下水のトリチウ 么濃度

Fig. 11 Fluctuation of tritium concentration of precipitation at Tokyo and Tsukuba City and discharged water at drain borings

における雨水の平均トリチウム濃度は緯度に依存してい る。長岡市とつくば市の緯度差は 1.5 度程度と小さいの で，本試験地における降水のトリチウム濃度が概ねつく ば市の值に近いと仮定すると，降水のトリチウム濃度は この20年程度は $10 \mathrm{TU}$ 前後である。表一 2 に示す水抜き ボーリング孔における排水中のトリチウム濃度は3.0 6.0TUであり，その上限值（減衰曲線 1 ），下限值（減 衰曲線 2 ）について半減期12.3年の減衰曲線を図－11に 示した。滅衰曲線が降水のトリチウム濃度と交差する最 近の年は1991年である。これより，採取された試料は， 少なくとも降雨による浸透後 10 年以上が経過している地 下水であると考えられる。また観測当初にNo. 85 孔と No. 89孔において $3.0 \sim 3.5 \mathrm{~Bq} / \ell$ という比較的低い值の トリチウム濃度が観測されたことから, 排水ボーリング 施工当初の排水の一部は化石水であった可能性がある。

水抜きボーリングからの地下水のラドン濃度は漸減傾 向にある(図一 7 )。地下水のラドン濃度は, 帯水層の ラジウム含有量により数 $\mathrm{Bq} / \ell$ 〜数十 $\mathrm{Bq} / \ell$ の帯水層固 有の放射平衡濃度を示す。放射平衡に達するまでの期間 は約 3 週間である。帯水層からのラドンの供給が絶たれ ると，放射崩壊によりラドン濃度は殆ど 0 となるので, 地表水が比較的短時間で地下水面に到達する場合はラド ン濃度が浸透水のトレーサーとなりうる（濱田ら1997）。 また，不飽和水のラドン濃度は飽和している状態に比べ て低く，ラドン濃度は飽和度と正の相関関係にあるので, 地下水のラドン濃度を定期的に測定することによって不 飽和浸透流の発生状況を明らかにすることが出来る(Hamada and Komae 1996)。ラドン濃度が時間の経過と共 に漸減する原因は次の二つの場合がある。

(1)排水トンネル施工によって地下水の流動状況が変化し, 濃度の低い地表水（降水を含む）が，放射平衡に達す る前に排水ボーリングへ供給された。

(2)トンネル周辺の地下水が排水され, 周辺に不飽和の領

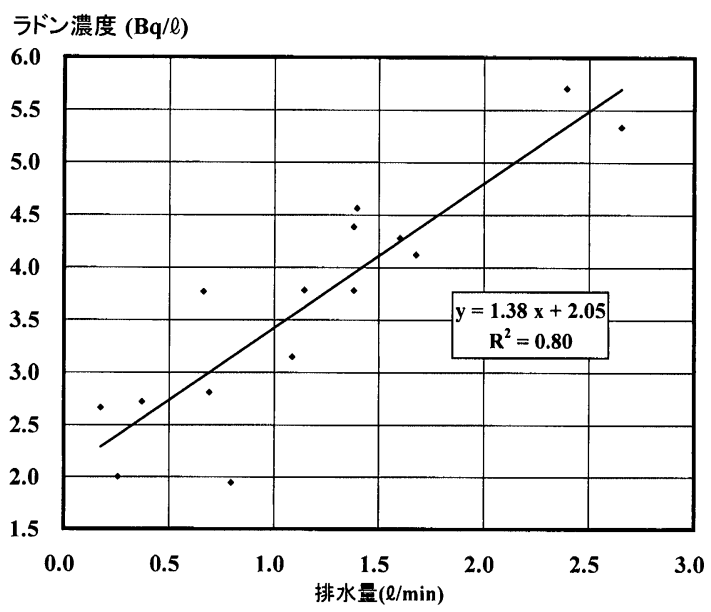

図-12 排水ボーリングからの排水量とラドン濃度との関係

Fig. 12 Relationship between the volume of discharged water and ${ }^{222} \mathrm{Rn}$ concentration

域が形成され,ガス分圧によってラドン濃度が減少した。 本調査地点近傍（12AB33からの距離約50m）のボーリ ング調査において，深度 $5 \mathrm{~m}$ 毎の揚水試験によって求め た透水係数は，深度10～40mの区間で $3.53 \times 10^{-5} \mathrm{~cm} / \mathrm{s} \sim$ $1.06 \times 10^{-6} \mathrm{~cm} / \mathrm{s}$ 小さかった。この事と排水ボーリン グの深度が $50 \mathrm{~m}$ 以上深いこと, トリチウム濃度によっ て推定される地下水の滞留時間が，ラドンの放射平衡期 間より遙かに長いことから，ラドン濃度の聥減は地表水 の混入によるものと考えるよりは，排水ボーリング周辺 地山において不飽和の部分が発生したと考える方が合理 的である。

不飽和水中のラドン濃度を $C u(\mathrm{~Bq} / \ell)$, 飽和水中の ラドン濃度をC $\mathrm{s}(\mathrm{Bq} / \ell)$ とすると, その濃度比 $r=C u$ /Csは次式で定義される（Hamada and Komae 1996）。

$$
\begin{aligned}
& r=D w S r /\{D w S r+D a(100-S r)\} \times(100 / S r) \\
& =100 D w /\{D w S r+D a(100-S r)\} \\
& D w \text { : 水に対するラドンの分配係数 } \\
& D a \text { : 空気に対するラドンの分配係数 }(D a=1) \\
& S r \text { : 飽和度 (\%) } \\
& \text { またDwは水温 } T\left({ }^{\circ} \mathrm{C}\right) \text { によって変化し， }
\end{aligned}
$$$$
D w=9.12 /(17.0+T)
$$

の近似式が与えられている（野口1975）。観測開始当初 （1998年12月）のラドン濃度（No. 85孔で5.90Bq/ $\ell$, No. 89 孔 で $4.89 \mathrm{~Bq} / \ell$, No. 93 孔 で $4.16 \mathrm{~Bq} / \ell)$ を $C s$ と し, 5 年後の同じ時期 (2003年12月) のラドン濃度 (No. 85 孔で2.87Bq/ $\ell$, No. 89 孔で3. $20 \mathrm{~Bq} / \ell$, No. 93 孔で2.09 $\mathrm{Bq} / \ell)$ を $\mathrm{Cu}$ とし, 水温をこの時期の平均的な地下水 温13.0度としてそれぞれの飽和度 $S r$ を求めると, No. 85 孔で $S r=54 \%$, No. 89 孔 $57 \%$ となり，それぞれの孔で程度の差はあるが飽和度が 低下している。

図-12に，排水ボーリングからの排水量とラドン濃度 
の関係を示す。両者の間には正の相関が見られ，直線近 似式

$$
\begin{aligned}
& y=1.38 x+2.05 \\
& x \text { : 排水量 }(\ell / \mathrm{min}), y \text { : ラドン濃度 }(\mathrm{Bq} / \ell) \\
& \text { における相関係数 } R \text { は } \\
& R^{2}=0.80
\end{aligned}
$$

であった。全体的にばらつきはあるが，排水量が小さく なるとラドン濃度も低下する傾向にあり，前記した(2)と 整合的である。

\section{3 地下水排除工の効果}

水分検層結果と放射性同位体测定結果を総合的に解釈 すると，以下のとおりである。排水トンネル周辺の地下 水は降雨漫透後 10 年以上経過したもので, 地下水の水循 環速度は比較的遅い。排水ボーリングの施工当初は, 排 水可能な地下水の量が排水ボーリングの能力を超えてい るので，排水量は比較的高いレベルで推移する。この間 周辺地山の排水が進むのですべり面の含水比は低下する。 トンネル地山周辺の排水が進み，排水量が地下水の供給 量と定常状態に達した後は排水量が減少する。その結果 として地山に不飽和の部分が発生してラドン濃度が低下 する。以上より本調査地点においては排水ボーリングの 効果が発現しており，排水ボーリングの排水能力を上回 る地下水の供給も見られない事から，排水ボーリングの 追加等の必要性は無いと言える。ただし，この結果はあ くまで調查地点周辺におけるものであるので，トンネル 全体についての効果を判定するためには, 調査点数を増 やして同様の傾向を確認する必要がある。

\section{6. まとめ}

本研究では新潟県中頸城郡板倉町の地すべり排水トン ネル内に掘削された観測孔および水抜きボーリング孔に おいて中性子水分検層, 地下水中のラドン・トリチウム 濃度測定を行い，地下水排除工の施工による地下水流動 状況の変化を調査した。結果は以下の通りである。

1）トンネル周辺地山の含水比測定では，すべり面の深 度が推定された。すべり面での含水比は当初 4 ケ月 間は減少を続け，その後は漸減した。含水比の減少 が比較的大きかった期間は, 観測孔周辺の排水ボー リングからの排水量も比較的大きく，含水比の減少 が少なかった期間は，排水量も小さく，両者は調和 的であった。

2）トリチウム濃度測定からは，排水トンネルから排出 される地下水は, 降雨浸透後 10 年以上経過したもの であり, 調查地内では地表水が短期間で排水トンネ ルに排出される様な地下水流動は起こっていないこ とが明らかになった。

3 ）ラドン濃度測定からは，排水ボーリングから排出さ れた地下水のラドン濃度が漸減傾向にあることが明 らかになり，排水トンネルによる排水が定常状態に 達し，周辺地山に不飽和部分が生じていると推定さ
れた。

以上, 従来は排水ボーリングからの排水量から推測す るしかなかった地下水流動の定常化，すべり面の含水比 低減が，中性子水分検層，環境同位体の測定により明ら かにされ，排水トンネルの効果判定に対するこれらの手 法の有効性が示された。今後これらの手法が排水トンネ ルの効果判定に活用されることが期待される。

\section{参考文献}

Andersen, L.J. and T.Sevel (1974) : Six years' environmental tritium profile in the unsaturated and saturated zones, Grohoj Denmark., Isotope Technique in Groundwater Hydrology Vol. 1, IAEA, pp. 3-20.

Dennis F. Sinclair and John Williams (1979) : Components of Variance Involved in Estimating Soil Water Content and Water Content Change Using a Neutron Moisture Meter, Aust. J. Soil Res,, 17, pp. $237-247$.

Gardner, W. and Kirkham, D.(1952) : Determination of soil moisture by neutron scattering, Soil Sci., 73, pp. 391-401.

Hamada H. and Komae T.,(1996) : Investigation on shallow groundwater in a small basin using natural radioisotopes, Radioisotopes, 45 , pp. $71-81$.

濱田浩正・今泉眞之・小前隆美（1997）：ラドン濃度を指標とした 地下水調查・解析法, 農業工学研究所報告, 36, pp. 17-50.

原 郁男・備前信之・野添浩彦・和田清男（2003）：巨大地すべり における排水トンネル施工とガス対策，地すべり，40(3)， pp. $17-22$.

北陸農政局計画部資源課（1993）：農地保全基礎調査特殊地すべり 对策調查北陸地区報告韭 資料編，pp. 83-84.

北陸農政局上越農地保全事業所（2001）：農林水産省直轄地すべり 対策事業板倉地区概要図.

細谷裕士（1992）：直轄地すべり対策事業板倉地区（農林水産省構 造改善局所管）における地すべり抑止杭について，地すべ り, 29(1), pp. 31-37.

今泉眞之 · 小前隆美 - 二平聡 (2000)：東京都に扔ける被圧地下水 の涵養機能一長期間のトリチウム濃度変化による涵養機能評 価一，応用地質，41(2)，pp. 87-102.

今泉眞之（1996）：中性子水分㭘層による第三紀層泥岩地すべり地 のすべり面の判定方法，地すべり，32(4), pp. 9-18.

International Atomic Energy Agency (1969, 1970, 1971, 1973, 1975, 1979, 1983) : Environmental Isotope Data No. 1 - 7, World Survey of Isotope Concentration in Precipitation, IAEA.

開発一郎・佐倉保夫（1979）：散乱型中性子水分計の使用に関する 問題，筑波大学水理実験センター報告，No. 3, pp. 39-46.

紀平潔秀 (1989）：すべり面の構造についての事例研究, 地すべり, 26(2), pp. $9-16$.

百田博宣・佐藤邦明（1985）：割れ目系地山のトンネル・空洞を対 象とした地下水の三次元挙動の解析, 土木学会論文集, 364 (III $-4)$, pp. $41-50$.

中村和善（1982）：新潟県高田平野南方地域における後期新生代の 構造運動, 地質学雑誌, 88(3), pp. 155-175.

仲野良紀・中里裕臣（1993）：地すべり粘土の自然含水比と間隙水 圧，第32回地すべり学会研究発表講演集，pp. 279-282.

仲野良紀 - 嶋崎藤雄 - 清水英良 (1992)：珪藻土質泥岩の力学的異 方性と限界伸びひずみについて, 農土論集, (141), pp. 121-130.

野口正安（1975）：特殊な利用法(2) ラドンの測定, Radioisotopes, $24(10)$, pp. 69 .

申潤植（1989）：地すべり工学－理論と実践一, 山海堂, pp. 1002.

高島良正 (1991)：環境トリチウムーその挙動と利用, Radioisotopes, 40 , pp. $520-530$.

竹内篤雄 - 内藤光雄（1992）：地下水排除工と効果判定とその実例, 地下水学会誌, 34, pp. $13-30$.

（原稿受付2004年 5 月 12 日，原稿受理2004年10月18日） 